\title{
Pengaruh Audit Commitee Expertise, Kualitas Audit, Dan Size Terhadap Internal Control Weakness SOX 404 Pada Perusahaan Perbankan Di Bei Periode 2015-2016
}

\author{
INDARTI INDARTI ${ }^{1}$, RINAYANTI RASYAD ${ }^{2}$, IKA BERTY APRILIYANI ${ }^{3}$ \\ Universitas Lancang Kuning \\ Jln. Yos Sudarso KM 08 Rumbai Telp. (0761) 52581 \\ E-mail : indarti.sam9@gmail.com
}

\begin{abstract}
This study aims to determine the effect of Audit committee Expertise, Audit Quality and Size to internal disclosure Control Weakness SOX 404. The data used is secondary data. The population in this study is a Banking company listed on the Indonesia Stock Exchange 2015-2016. Determination of sample research using purposive sampling method and data processing using multiple linear regression. The result of research that Variable Audit Commitee Expertise influence to the Disclosure of weakness of Internal Control. While Quality Audit and company size (Size) do not have a strong influence on the disclosure of the weakness of Internal Control.
\end{abstract}

Keywords: Audit commite Expertise, Kualitas Audit dan Size terhadap pengungkapan internal Control Weakness SOX 404.

Salah satu aspek penting dari SOX adalah terdapat dua bagian khusus berfokus pada isu-isu pengendalian internal terkait dengan pelaporan keuangan. Menurut Section 302, manajemen diwajibkan untuk mengungkapkan semua kelemahan material dalam pengendalian internal, pada saat mereka mengesahkan laporan keuangan baik secara periodik, tahunan dan triwulanan. Menurut Section 404, perusahaan diwajibkan untuk menilai efektivitas struktur pengendalian internal dan prosedur dalam pelaporan keuangan dan mengungkapkan informasi tersebut dalam laporan tahunannya, Y. Zang, et al. (2007). Y. Zang, et al. (2007) menyatakan bahwa ada hubungan antara kualitas komite audit, independensi auditor, dan kelemahan pengendalian internal. Suatu perusahaan cenderung ditemukan adanya kelemahan pengendalian internal jika perusahaan tersebut memiliki komite audit dengan sedikit financial expert atau, secara khusus lebih sedikit memiliki keahlian akuntansi dan/atau keuangan dan non-keahlian akuntansi keuangan. Selain itu kelemahan pengendalian internal dapat juga diidentifikasi jika auditor internal dalam perusahaan tersebut lebih banyak yang independen. Hal lainnya yang menyebabkan kelemahan pengendalian internal adanya perubahan auditor.

Pengungkapan yang diwajibkan dalam SOX 2002 sebagian besar terkait dengan pengendalian internal (Yan Zhang, 2007), sehingga pada penelitian ini akan lebih difokuskan pada faktor-faktor yang berhubungan dengan pengungkapan kelemahan pengendalian internal. Sedangkan untuk periode penelitian ini akan lebih difokuskan pada era setelah penetapan SOX atau lebih dikenal dengan postSOX era.

Pada SOX 404 mewajibkan manajemen untuk membuat penilaian terhadap pengendalian internal perusahaan dan juga mewajibkan auditor untuk memberikan opini terhadap penilaian manajemen tersebut. Berdasarkan Securities Exchange Commission (SEC) ReleaseNo. 33-8238 (5 Juni 2003), section404(a) mewajibkan emiten untuk mengungkapkan informasi mengenai ruang lingkup dan kecukupan dari struktur dan prosedur pengendalian internal untuk pelaporan keuangan 
dalam laporan tahunannya. Section 404(b) mewajibkan perusahaan auditing yang sudah teregister untuk membuktikan dan melaporkan efektivitas struktur dan prosedur pengendalian internal.

Di Indonesia, pengungkapan kelemahan pengendalian internal belum banyak ditemui karena masih bersifat voluntary (sukarela). Namun apabila sebuah perusahaan telah terdaftar di bursa efek Amerika Serikat, maka perusahaan tersebut wajib melakukan pengungkapan kelemahan pengendalian internal karena terikat oleh peraturan dari SOX. Dalam SOX 404, pihak manajemen diwajibkan untuk melakukan penilaian terhadap efektivitas struktur dan prosedur pengendalian internal dalam pelaporan keuangannya. Setelah itu auditor perusahaan diwajibkan untuk memberikan opini terhadap penilaian yang dilakukan oleh manajemen perusahaan tersebut. Dalam hal ini independensi auditor sangat diperlukan untuk dapat menilai efektivitas pengendalian internal perusahaan tersebut. Hasil penelitianpenelitian sebelumnya dan berbagai penjelasan di atas mendorong perumusan masalah berikut ini :

1). Apakah Pengaruh Audit Commitee Expertise berpengaruh terhadap internal control weakness SOX 404.

2). Apakah Pengaruh Kualitas Audit berpengaruh terhadap terhadap internal control weakness SOX 404.

3). Apakah Pengaruh Size terhadap berpengaruh terhadap internal control weakness SOX 404.

4). Apakah Pengaruh Audit Commitee Expertise, Kualitas Audit, dan Ukuran Perusahaan berpengaruh terhadap terhadap internal control weakness SOX 404.

Sarbanes-Oxley Act of 2002 (SOX 2002) adalah undang-undang yang dipraskarsai oleh Senator Paul Sarbanes (Maryland) dan Representative Michael Oxley (Ohio). Salah satu hal yang melatarbelakangi lahirnya SOX adalah kasus yang menimpa Enron, WorldCom, Tyco, dan beberapa perusahaan besar AS. Setelah terjadinya skandal yang melibatkan perusahaan-perusahaan tersebut, para shareholders memiliki persepsi bahwa perusahaan publik memiliki kemungkinan besar untuk melakukan kecurangan saat menjalankan perusahaannya. Dengan terjadinya skandal tersebut, badan legislasi Amerika Serikat merasa terpanggil untuk membuat sebuah undang-undang yang dapat melindungi para shareholders. Standar auditing yang telah ada pada saat tersebut dinilai belum mampu untuk mencegah terjadinya fraud, sehingga muncullah SOX yang dianggap lebih mampu untuk mencegah terjadinya frauddalam perusahaan.

Kelemahan Pengendalian Internal (Internal Control Weakness-ICW)

Masalah terkait pengendalian internal dibedakan dalam tiga jenis, yaitu: kelemahan material (material weakness), kekurangan yang signifikan (significant deficiency), dan kekurangan pengendalian (control deficiency) (Yan Zhang et. al, 2007). Menurut Auditing Standard (AS) No. 2 (dalam Yan Zhang et. al, 2007) kelemahan material adalah kekurangan yang signifikan atau kombinasi dari kekurangan yang signifikan yang menyebabkan salah saji material pada laporan keuangan tahunan dan laporan keuangan interim tidak dapat dicegah atau dideteksi. Kekurangan yang signifikan menurut AS No. 2 (dalam Yan Zhang et. al, 2007) adalah kekurangan pengendalian yang mempengaruhi kemampuan perusahaan untuk memulai, mengotorisasi, mencatat, proses, atau melaporkan data keuangan yang andal kepada pihak eksternal sesuai dengan prinsip akuntansi berterima umum. 3). Kualitas Komite Audit

Kualitas komite audit dalam hal ini dapat dilihat dari keahlian yang dimiliki oleh anggota komite audit. Keahlian 
komite audit dibedakan menjadi dua macam. Pertama adalah keahlian dalam bidang akuntansi keuangan dan yang kedua adalah keahlian non akuntansi keuangan. DeFond et al. (2005) membuktikan akumulasi returnpositif yang signifikan pada penunjukan ahli akuntansi keuangan pada komiteaudit, dan menganjurkan bahwa komite audit dengan keahlian akuntansi keuangan akan dapat memperbaiki tata kelola perusahaan. Oleh karena itu dalam penelitian ini keahlian komite audit akan dibedakan dalam dua kategori yaitu keahlian dalam bidang akuntansi keuangan dan non-akuntansi keuangan. Selanjutnya akan diuji hubungan dengan pengungkapan pengendalian internal.

\section{1). Keahlian akuntansi keuangan}

Menurut DeFond et al. (2005) seseorang dapat dikatakan sebagai ahli akuntansi keuangan apabila telah memiliki pengalaman sebagai akuntan publik, auditor, prinsipal atau chief financial officer (CFO), kontroler, atau prinsipal atau chief accounting officer.

2). Keahlian non-akuntansi keuangan

Menurut DeFond et al. (2005) seseorang dapat dikatakan sebagai ahli nonakuntansi keuangan adalah seseorang yang telah berpengalaman sebagai chief executif officer (CEO), presiden direktur, kepala dewan dalam sebuah perusahaan yang berorentasi profit, atau seseorang yang berpengalaman sebagai managing director, partner atau prinsipal dari sebuah perusahaan ventura, investment banking, atau manajer keuangan.

Keahlian keuangan dari anggota komite audit itu menunjukan sesuatu yang penting dalam hubungannya dengan kompleksitas laporan keuangan (Kalbers and Fagarty, 1993) dan untuk mengurangi penyajian kembali laporan keuangan (Abbott et al., 2004). DeZoort dan Salterio (2001) menemukan bahwa anggota gan dan auditing akan lebih dapat memahami jugdment auditor dan bisa memberikan dukungan kepada auditor apabila terjadi perselisihan antara auditor dan manajemen dibandingkan dengan auditor yang tidak memiliki pengertahuan tersebut. Selain itu, anggota yang memiliki pengetahuan yang lebih banyak dalam bidang keuangan memiliki kemungkinan yang lebih besar untuk dapat menunjukkan dan mendeteksi salah saji material. Anggota komite audit dengan keahlian keuangan juga dapat memainkan peran dalam pengawasan proses pelaporan keuangan secara lebih efektif, seperti mendeteksi adanyan salah saji material (Scarbrough et al., 1998; Raghunandan et al., 2001). Abbott et al., ( 2004) menemukan hubungan negatif yang signifikan antara komite audit yang memiliki paling tidak satu anggota dengan keahlian keuangan dan munculnya pelaporan kembali laporan keuangan. Sedangkan penelitian yang dilakukan Krisnan (2005) menunjukan bahwa komite audit yang memiliki keahlian keuangan memiliki kemungkinan yang lebih kecil untuk dihubungkan dengan munculnya masalah pengendalian internal. Dari penjelasan di atas, maka dirumuskan sebuah hipotesis, yaitu:

H1: Kualitas komite audit dengan keahlian keuangan berpengaruh terhadap internal control weakness SOX 404.

Berdasarkan Y.Zang et al. (2007) , kualitas audit diukur dengan memberi angka 1 apabila auditor perusahaan tersebut memiliki afiliasi dengan Big 4 dan 0 apabila tidak berafiliasi. Selain daripada itu, terdapat penelitian yang dilakukan oleh I Ketut Yadyana (2009) menyangkut tentang kualitas jasa auditor internal menghubungkannya dengan efektivitas pengendalian intern, menyatakan bahwa kualitas jasa auditor internal dalam proses pelaksanaan pemeriksaan intern sangat ditentukan oleh kemampuan auditor internal dalam menerapkan norma pemeriksaan intern dalam menjalankan tugasnya. Jika pengendalian intern perusahaan sudah ditempatkan dan 
berjalan dengan baik dalam pengawasan auditor internal, maka peluang adanya kecurangan yang tidak terdeteksi akan berkurang.

$\mathrm{H} 2$ : Kualitas Audit berpengaruh terhadap internal control weakness SOX 404.

Perusahaan berukuran besar memiliki kelemahan pengendalian internal yang lebih sedikit dibandingkan dengan perusahaan kecil. Perusahaan besar cenderung memiliki kelebihan dalam mengembangkan dan mengimplementasikan pengendalian internal perusahaan. Perusahaan besar memiliki lebih banyak sumber daya untuk menyewa auditor eksternal yang dapat membantu mendesain pengendalian internal yang kuat. Sebaliknya, perusahaan kecil memiliki kesulitan dalam mengevaluasi pengendalian internal dikarenakan belum mempunyai struktur yang formal atau struktur yang baik dalam pengendalian internal mereka. Perusahaan kecil cenderung mempunyai sumber daya yang terbatas, termasuk sumber daya yang dikhususkan untuk mendesain dan menerapkan pengendalian internal yang efektif dan masuk akal. Komponen pengendalian internal, seperti pemisahan tugas, relatif lebih sulit untuk diterapkan di perusahaan kecil.

H3: Ukuran Perusahaan berpengaruh terhadap internal control weakness SOX 404.

Perancangan model penelitian bertujuan agar lebih memahami konsep penelitian dan arah dari hubungan variabel independen terhadap variabel dependen. Model penelitian yang digunakan dalam penelitian ini menunjuk kan gambaran tentang variabel proksi independen financial stability,external pressure,financial target, nature of industry, opini audit,dan pergantian direksi (CEO) memengaruhi variabel dependen yaitu kecurangan laporan keuangan (fraudulent financial statements). Berikut ini model penelitian yang digunakan oleh peneliti pada gambar 1 berikut ini:

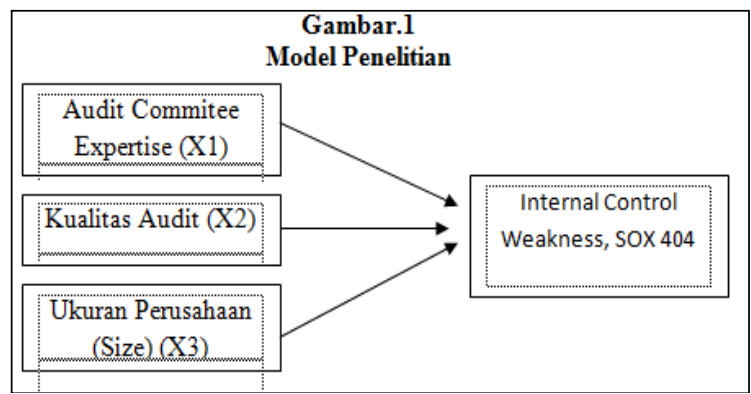

Adapun yang menjadi tujuan penelitian ini adalah

1). Untuk menganalisis pengaruh Audit Commitee Expertise terhadap pengungkapan kelemahan pengendalian internal SOX 404.

2). Untuk menganalisis pengaruh Audit Quality terhadap pengungkapan kelemahan pengendalian internal SOX 404.

3). Untuk menganalisis pengaruh Size terhadap pengungkapan kelemahan pengendalian internal SOX 404.

4). Untuk menganalisis pengaruh Audit Commitee Expertise, Audit Quality dan Size terhadap pengungkapan kelemahan pengendalian internal SOX 404.

\section{METODE}

Populasi dalam penelitian adalah seluruh perusahaan Perbankan yang terdaftar di Bursa Efek Indonesia. Metode pemilihan sample menggunakan metode purposive sampling yaitu pemilihan sampel berdasarkan tujuan penelitian dengan pertimbangan khusus. Adapun kriteria kriteria dalam pengambilan sampel yaitu:

1). Perusahaan Perbankan yang terdaftar di bursa efek Indonesia berturut - turut selama periode tahun 2015-2016

2). Perusahaan Perbankan yang mempublikasikan laporan keuangan tahunan dalam website perusahaan atau website BEI selama periode 2015-2016 yang dinyatakan dalam rupiah. 
3). Perusahaan yang mengungkapkan data -data berkaitan dengan variabel penelitian dan tersedia secara lengkap.

Variabel dependen dalam penelitian ini adalah pengungkapan kelemahan pengendalian internal SOX 404. Proksi yang digunakan dalam mengukur pengungkapan kelemahan pengendalian internal adalah adalah RMC (Risk Management Committee), dan training. Kategori 1 diberikan kepada perusahaan yang membentuk RMC, sedangkan kategori 0 diberikan kepada perusahaan yang tidak membentuk RMC.

Kelemahan Pengendalian Internal (Internal Control Weakness). Kelemahan pengendalian internal perusahaan dilihat dari pengungkapan material weakness yang dilakukan oleh perusahaan tersebut pada laporan tahunannya.

Apabila pada tahun yang bersangkutan perusahaan mengungkapan material weakness, maka perusahaan tersebut diidentifikasi mengalami kelemahan dalam pengendalian internal internalnya.

Variabel independen yang digunakan dalam penelitian ini adalah:

1). Audit committee financial experrts dan internal audit. Penelitian DeFond, et al. (2005) merumuskan audit committee financial experts diukur dari persentase anggota komite audit yang ahli dalam akuntansi dan/atau keuangan.

Pengukurannya:

- Keahlian dalam bidang keuangan (ACFE) diukur dari persentase anggota komite audit yang ahli dalam akuntansi dan/atau keuangan.

$$
\mathrm{ACFE}=\frac{\sum \text { Ahli akuntansi dan/atau keuangan }}{\sum \text { anggota komite audit }} \times 100 \%
$$

Dalam mengukur keahlian keuangan dari anggota komite audit, pada penelitian ini menggunakan definisi yang dianut di SOX Section 407, dan lebih khusus, memodifikasi definisi yang digunakan dalam DeFond et al. (2005). Seorang anggota komite audit adalah Ahli keuangan jika ia dapat diklasifikasikan ke dalam dua kategori berikut: a). Seorang ahli akuntansi keuangan yang memiliki pengalaman sebagai akuntan publik, auditor, kepala keuangan, controller, atau pokok atau kepala Petugas akuntansi; atau (b) seorang ahli keuangan non-akuntansi yang memiliki pengalaman sebagai CEO, presiden, atau ketua dewan dalam nirlaba korporasi, atau yang memiliki pengalaman sebagai direktur, mitra atau pokok dalam pembiayaan usaha, perbankan investasi, atau pengelolaan uang.

\section{2). Kualitas Audit}

Berdasarkan Y.Zang et al. (2007), Kualitas Audit diukur dengan memberi angka 1 apabila auditor perusahaan tersebut memiliki afiliasi dengan Big 4 dan 0 apabila tidak berafiliasi.

3). Ukuran perusahaan merupakan besar kecilnya perusahaan, yaitu besar dan kecil. Ukuran perusahaan diukur dengan nilai logaritma natural dari total aset yang digunakan perusahaan.

\section{HASIL}

Pada penelitian ini, data yang digunakan adalah laporan keuangan perusahaan perbankan yang terdaftar di Bursa Efek Indonesia (BEI) pada tahun 2015 - 2016, yang didapatkan dari Bursa Efek Indonesia (www.idx.co.id). Total perusahaan perbankan yang terdaftar di Bursa Efek Indonesia (BEI) pada tahun 2015 - 2016 adalah sebanyak 43 perusahaan.

Uji normalitas dengan analisis grafik dilakukan dengan metode grafik histogram dan Probability Plot (P-Plot). Selengkapnya mengenai hasil uji normalitas penelitian ini dapat dilihat pada Gambar 5.1 dan 5.2 berikut ini :

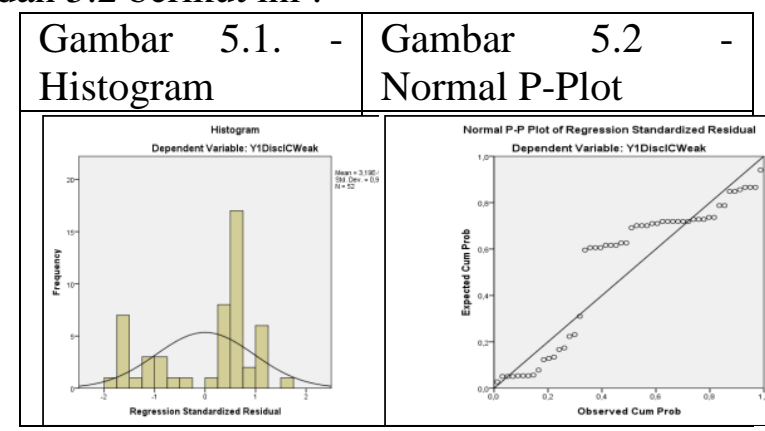

Jurnal Akuntansi Kompetif, Online ISSN:2622-5379 Vol. 1, No. 1, September 2018 
Dengan melihat tampilan pada grafik histogram dalam gambar 5.1. memberikan pola distribusi yang mendekati normal, sedangkan pada gambar 5.2. grafik normal probability plot menunjukkan titik-titik menyebar disekitar garis diagonal dan penyebarannya mengikuti arah garis diagonal. Maka dapat disimpulkan bahwa model regresi dalam penelitian ini telah memenuhi asumsi normalitas.

Uji multikolinearitas bertujuan untuk menguji apakah dalam model regresi ditemukan adanya korelasi antar variabel bebas (independen). Multikolinearitas dapat dilihat dari perhitungan nilai tolerance serta Variance Inflation Factor (VIF). Suatu model regresi disimpulkan tidak ada masalah multikolinearitas adalah apabila memiliki nilai tolerance lebih besar dari 0,10 dan nilai variance inflation factor (VIF) lebih kecil dari 10 (Ghozali, 2011:106). Selengkapnya hasil pengujian asumsi klasik multikolinearitas dapat dilihat pada tabel 5.1 berikut ini.

Tabel VIF (Variance Inflation Factor)

\begin{tabular}{|l|l|l|}
\hline \multirow{2}{*}{ Model } & \multicolumn{2}{|l|}{ Collinearity Statistics } \\
\cline { 2 - 3 } & Tolerance & VIF \\
\hline $\begin{array}{l}\text { (Constant) } \\
\begin{array}{l}\text { X1AudCom } \\
\mathrm{m}\end{array}\end{array}$ & 950 & 1,053 \\
$\begin{array}{l}\text { X2AudQuali } \\
\text { ty }\end{array}$ & 667 & 1,500 \\
\hline X3Size & 639 & 1,564 \\
\hline
\end{tabular}

a. Dependent Variable: Y1DiscICWeak

Dari tabel 5.1. di atas menunjukkan bahwa semua variabel independen memiliki nilai tolerance lebih besar dari 0,10 yang berarti tidak ada korelasi antar variabel independen yang nilainya lebih dari 95\%. Hasil perhitungan nilai Variance Inflation Factor (VIF) juga menunjukkan hal yang sama yaitu semua variabel independen memiliki nilai VIF lebih kecil dari 10. Maka dapat disimpulkan bahwa model regresi dalam penelitian ini telah terbebas dari masalah multikolinearitas.

Hasil uji koefisien determinasi dapat dilihat pada tabel berikut :
Tabel R Square

Model Summary

\begin{tabular}{|c|c|c|c|c|}
\hline del & $\mathbb{R}$ & $\begin{array}{l}\mathrm{R} \\
\text { Squ } \\
\text { are }\end{array}$ & \begin{tabular}{|l|l|} 
Adjus & Std. \\
ted R R & Error of \\
Squar & the \\
e & Estimate \\
\end{tabular} & $\begin{array}{l}\text { Durbi } \\
\text { n- } \\
\text { Watso } \\
n\end{array}$ \\
\hline &, $352^{\mathrm{a}}$ &, 124 & 45703 & 2,339 \\
\hline
\end{tabular}

a. Predictors: (Constant), X3Size, X1AudComm, X2AudQuality

$$
\text { b. Dependent Variable: }
$$

Y1DiscICWeak

Dari tabel di atas menunjukkan bahwa nilai $\mathrm{R}$ square sebesar 0,124 berarti bahwa hanya sebesar $12,46 \%$ variabel dependen yaitu Pengungkapan kelemahan pengendalian Internal dapat dijelaskan oleh variabel independen yaitu Audit Commitee Expertise, Audit Quality, dan Ukuran perusahaan. Hal ini menandakan masih rendah atau lemahnya kemampuan variabel independen dalam menjelaskan variabel dependen, sedangkan sisanya yaitu sebesar $81,6 \%$ dijelaskan oleh variabel lain yang tidak dimasukkan dalam penelitian ini.

\section{PEMBAHASAN}

Pengujian hipotesis dalam penelitian ini menggunakan analisis regresi linier berganda, untuk menguji hipotesis. Hal ini dilakukan untuk mengetahui pengaruh variabel independen terhadap variabel dependen secara parsial. Hal ini bertujuan untuk mengetahui pengaruh Audit Commitee, Audit Quality, dan Size terhadap pengungkapan kelemahan pengendalian Internal. Teknik analisis tersebut dilakukan dengan menggunakan program SPSS versi 22.

Berdasarkan gambar, diperoleh hasil bahwa Nilai probabilitas signifikansi sebesar 0,093 menunjukkan nilai yang lebih besar dari pada tingkat signifikansi yang telah ditentukan yaitu $0,05(0,093>$ 0,05). Berdasarkan hasil uji hipotesis tersebut, dapat dikatakan bahwa hipotesis Audit Commitee, Audit Quality, dan Size tidak berpengaruh secara simultan terhadap pengungkapan kelemahan pengendalian Internal.

Selengkapnya mengenai hasil uji statistik F 
penelitian ini dapat dilihat pada Tabel. berikut ini.

\begin{tabular}{|l|l|l|l|l|l|}
\hline Model & $\begin{array}{l}\text { Sum of } \\
\text { Squares }\end{array}$ & df & $\begin{array}{l}\text { Mean } \\
\text { Square }\end{array}$ & F & Sig. \\
\hline 1 Regressi & 1,416 & 3 &, 472 & 2,260 & b 093 \\
$\begin{array}{l}\text { on } \\
\text { Residual } \\
\text { Total }\end{array}$ & 10,026 & 48 &, 209 & & \\
\hline
\end{tabular}

a. Dependent Variable: Y1DiscICWeak

b. Predictors: (Constant), X3Size, X1AudComm, X2AudQuality

Dari tabel 5.3 di atas menunjukkan nilai $\mathrm{F}$ hitung sebesar 2,260 dengan nilai signifikansi sebesar 0,093. Hal ini menandakan bahwa model regresi dapat digunakan untuk menguji pengaruh variabel independen terhadap Pengungkapan kelemahan pengendalian Internal karena nilai signifikansi lebih besar dari 0,05 (sig $>5 \%$ ). Maka dapat disimpulkan Hipothesis ditolak yang menunjukkan bahwa tidak terdapat pengaruh yang signifikan dari Audit Commitee, Audit Quality, dan Size terhadap pengungkapan kelemahan pengendalian Internal.

Uji statistik $t$ bertujuan untuk mengetahui seberapa jauh pengaruh variabel independen secara individual (parsial), yaitu Audit Commitee, Audit Quality, dan Size terhadap pengungkapan kelemahan pengendalian Internal. Model regresi pada penelitian ini diuji dengan melihat nilai sig yang terdapat pada tabel 5.4. berikut ini.

Uji t

\begin{tabular}{|c|l|l|l|l|l|}
\hline & \multicolumn{2}{|l|}{$\begin{array}{l}\text { Unstandardiz } \\
\text { ed }\end{array}$} & $\begin{array}{l}\text { tandar } \\
\text { dized } \\
\text { Coefficients }\end{array}$ & $\begin{array}{l}\text { Coffici } \\
\text { ents }\end{array}$ & \\
\cline { 2 - 5 } Model & B & $\begin{array}{l}\text { Std. } \\
\text { Error }\end{array}$ & Beta & $t$ & Sig. \\
\hline $\begin{array}{l}1 \quad \text { Constant } \\
\text { ) } \\
\text { X1AudC } \\
\text { omm }\end{array}$ &, 430 & 1,093 & &, 394 &, 696 \\
$\begin{array}{l}\text { X2AudQ } \\
\text { uality }\end{array}$ &,- 106 &, 168 &,- 104 &,- 628 &, 533 \\
\hline X3Size &,- 012 &, 048 &,- 043 &,- 255 &, 800 \\
\hline
\end{tabular}

Dependent Variable: Y1DiscICWeak

Berdasarkan hasil uji statistik t pada tabel di atas, maka diperoleh persamaan regresi sebagai berikut:

Disclosure ICWeakness $=0,726$ Audit Comm Expertise - 0,0106 Audit Quality 0,012 Size $+\varepsilon$

Dari persamaan regresi di atas, diketahui bahwa konstanta sebesar 0,726 menyatakan bahwa apabila variabel independen yang terdiri Audit Commitee Expertise terhadap pengungkapan kelemahan Pengendalian Internal sebesar 0,726. Variabel Kualitas Audit memiliki koefisien regresi negatif dan Size memiliki koefisien negatif. Hal ini berarti bahwa perusahaan dengan Audit Commitee Expertise mempengaruhi adanya pengungkapan Kelemahan pengendalian internal. Selain itu jika dilihat dari signifikansinya maka Audit Commitee Expertise berpengaruh terhadap pengungkapan kelemahan Pengendalian Internal sebesar 0,018. Dengan adanya pengawasan yang tinggi dari Audit Commitee yang berpengalaman di bidang Akuntansi dan keuangan maka akan maka akan mempengaruhi dalam hal pengungkapan kelemahan pengendalian Internal, karena diharapkan akan meningkatkan transparansi dan kehatihatian dalam menjalankan operasional perusahaan.

Dengan kualitas audit yang baik, belum tentu pengungkapan tentang kelemahan pengendalian Internal disampaikan dalam laporan keuangan, karena tergantung kepada pihak manajemen apakah besedia untuk memberikan pengungkapan kelemahan pengendalian Internal tersebut. Pihak external Audit hanya memberikan saran kepada manajemen untuk menyampaikan hal yang sebenarnya tentang kondisi kelemahan pengendalian Internal Internal pada perusahaan yang bersangkutan.

Ukuran Perusahaan atau Size tidak berpengaruh terhadap pengungkapan tentang kelemahan pengendalian Internal. Hal ini dikarenakan semakin besar aset perusahaan, biasanya diikuti dengan pengendalian internal yang kuat pula, sehingga kelemahan pengendalian internal 
bisa dikurangi.

\section{SIMPULAN}

Berdasarkan hasil penelitian diatas, maka diperoleh kesimpulan sebagai berikut: Variabel Audit Commitee Expertise berpengaruh terhadap pengungkapan Kelemahan pengendalian Internal. Dengan Komite Audit yang berpengalaman (Audit Commitee Expertise) akan berpengaruh terhadap pengungkapan Kelemahan pengendalian Internal. Hal ini menunjukkan dengan pengawasan yang lebih baik dari Audit Komite yang berpengalaman, akan meningkatkan kesadaran meningkatkan pengendalian internal dan pengungkapan kelemahan pengendalian internal akan disampaikan untuk memberikan rasa awareness dan kehati-hatian dalam menjalankan operasional perusahaan.

Variabel Audit Quality tidak berpengaruh terhadap pengungkapan Kelemahan pengendalian Internal. Dengan kualitas audit yang baik tidak akan berpengaruh terhadap pengungkapan Kelemahan pengendalian Internal. Hal ini menunjukkan bahwa meskipun dengan kualitas audit yang baik yang dilihat dari audit eksternal, tidak berpengaruh terhadap pengungkapan kelemahan pengendalian internal. Hal ini dikarenakan karena tergantung kepada pihak manajemen apakah besedia untuk memberikan pengungkapan kelemahan pengendalian Internal tersebut. Pihak external Audit hanya memberikan saran kepada manajemen untuk menyampaikan hal yang sebenarnya tentang kondisi kelemahan pengendalian Internal Internal pada perusahaan yang bersangkutan.

Variabel Size tidak berpengaruh terhadap pengungkapan Kelemahan pengendalian Internal. Ukuran Perusahaan atau Size tidak berpengaruh terhadap pengungkapan tentang kelemahan pengendalian Internal. Hal ini dikarenakan semakin besar aset perusahaan, biasanya diikuti dengan pengendalian internal yang kuat pula, sehingga kelemahan pengendalian internal bisa dikurangi.

Secara bersamaan Variabel Audit
Commitee Expertise, Audit Quality, Size tidak berpengaruh terhadap pengungkapan Kelemahan pengendalian Internal. Karena masih banyak faktor-faktor lain yang mempengaruhi pengungkapan Kelemahan pengendalian Internal.

Untuk memperoleh penelitian yang lebih baik sebaiknya penelitian berikutnya memperluas sampel penelitian dan pengujian pengamatan yang lebih lama sehingga dapat memberikan hasil yang lebih baik. Peneliti selanjutnya hendaknya dapat menambahkan variabel lain yang dapat berperan dalam mempengaruhi pengungkapan kelemahan pengendalian internal dalam laporan tahunan perusahaan, seperti profitabilitas, laju pertumbuhan, kompleksitas transaksi.

\section{DAFTAR RUJUKAN}

Abbott, L., Parker, S., dan Peters, G., 2004. Audit Committee Characteristics And Restatements. Auditing: A Journal of Practice and Theory 23 (1),69-87.

DeFond, M., Hann, R., Hu, X., 2005. Does the Market Value Financial Expertise on Audit Committees of Boards of Directors?. Journal of Accounting Research 43 (2), 153-193.

DeZoort, F., Salterio, S., 2001. The Effects of Corporate Governance Experience and Financial Reporting and Audit Knowledge on Audit Committee Members' Judgments. Auditing: A Journal of Practice and Theory 20 (2), 31-47.

Ghozali, Imam. 2011. Aplikasi Analisis Multivariate dengan Program IBM SPSS 19. Semarang: Badan Penerbit Universitas Diponegoro.

Hoitash, Rani. and Udi Hoitash.2008. The Role of Audit Committees in Managing Relationships with 
External Auditors afterSOX

Evidence from the USA.

Managerial Auditing Journal Vol. 24 No. 4, 2009 pp.368-397. http://www.idx.co.id/

Kalbers, L., Fogarty, T., 1993. Audit Committee Effectiveness: An Empirical Investigation of the Contribution Of Power. Auditing: A Journal of Practice \& Theory 12 (1), 24-49.

Kinney, W., 2001. Accounting Scholarship: What is uniquely ours?. The Accounting Review 76 (2): 275-284.

Klein, A., 2002a. Economic determinants of audit committee independence. The Accounting.Review 77 (2), 435452.

Krishnan, J., 2005. Audit Committee Financial Expertise and Internal Control: An Empirical Analysis. The Accounting Review 80 (2), 649-675.

Mautz, R. 1980. Internal Control: Contrasts and Confusion. Saxe Lectures, University of Michigan.

Raghunandan, K., Read, W., dan Rama, D., 2001. Audit Committee Composition, "Gray Directors," and Interaction with Internal Auditing. Accounting Horizons 15 (2), 105-118.

Widhiarso, Wahyu.2011. Analisis Data Penelitian dengan Variabel Kontrol.http://widhiarso.staff.ugm.a c.id. diaksestanggal 16 Maret 2012

Zhang, Yan., Jian Zhou, dan Nan Zhou. 2007. Audit Committee Quality, Auditor Independence, and Internal Control Weaknesses.
Journal of Accounting and Public Policy 26 (2007) 300-327”. 